\title{
WATER RECYCLING OPPORTUNITY IN THE BUSINESS SECTORS OF GREATER JAKARTA, INDONESIA
}

\author{
Cindy R. Priadi ${ }^{1 *}$, Evelyn Suleeman ${ }^{2}$, Linda Darmajanti ${ }^{2}$, Shanty Novriaty ${ }^{2}$, Nyoman \\ Suwartha ${ }^{1}$, Rina Resnawati ${ }^{1}$, Rahayu Handayani ${ }^{3}$, Gita L. Putri ${ }^{1}$, Elzavira Felaza ${ }^{1}$, Tri Tjahjono ${ }^{1}$ \\ ${ }^{1}$ Department of Civil Engineering, Faculty of Engineering, Universitas Indonesia, Kampus UI \\ Depok, Depok 16424, Indonesia \\ ${ }^{2}$ Department of Sociology, Faculty of Social and Political Sciences, Universitas Indonesia, Kampus \\ UI Depok, Depok 16424, Indonesia \\ ${ }^{3}$ School of Environmental Science, Postgraduate Faculty, Universitas Indonesia, Kampus UI \\ Depok, Depok 16424, Indonesia
}

(Received: February 2017/ Revised: May 2017 / Accepted: November 2017)

\begin{abstract}
With an increasing population, the effects of climate change and limited water resources, water reuse is an option that must be explored in order to reduce the high water stress in Indonesia. This study aims to identify enablers of, barriers to, and opportunities for early adopters of water recycling in the business sector of the Greater Jakarta region of Indonesia, and to highlight the possibilities of its wider implementation in order to reduce water stress. Semi-structured interviews, desk reviews, and observations were conducted with eight enterprises. Most respondents demonstrated that their main purpose for recycling water is to reduce costs. Recycled water was mostly used where there are minimal possibilities of direct contact with people to reduce the impact of social barriers. While the absence of a clear legal framework was identified as another barrier to water recycling implementation, this can also serve as an enabler. The decrease in raw water quality makes water recycling a cost-effective solution. Considering all findings, water recycling in Indonesia has great potential to be more widely applied and to be supported by related stakeholders.
\end{abstract}

Keywords: Best practice; Water recycling; Water reuse; Water quality

\section{INTRODUCTION}

Indonesia has the fifth-largest water reserves in the world. However, only $17 \%$ of the water is usable and only $25 \%$ of that amount is successfully used (Ministry of Public Works, 2014). In the capital region of Greater Jakarta, minimal usability is caused by the degeneration of the city's water quality, resulting from the heavy pollution of its water sources (Apip et al., 2015), especially in its major supplier, Jatiluhur Reservoir (Corsita et al., 2014). Based on Water Quality Standard Class I in Government Regulation No. 82 of 2001, chemical parameters indicated pollution (Hamzah, 2016). Degenerating surface water quality has resulted in an upward trend of groundwater usage in business sectors in Greater Jakarta. To conserve groundwater, a usage restriction has been issued through Regulation of the Minister of Energy and Mineral Resources No. 15 of 2012. However, in its implementation, the piped water supply could not meet the actual water demand, partly due to a high investment cost (Hidayatno et al., 2015). The amount of surface water supplied to the industry is only $1 \%$ of the volume required (Delinom, 2008).

\footnotetext{
*Corresponding author's email: cindy.priadi@eng.ui.ac.id, Tel. +62-21-7270029, Fax.+62-21-7270028 Permalink/DOI: https://doi.org/10.14716/ijtech.v8i6.743
} 
The reuse of treated wastewater for various purposes, such as agricultural and landscape irrigation, industrial processes, sanitation, or groundwater recharge, can be a sustainable alternative solution to the water crisis problem (US EPA, 2012). Unfortunately, implementation is not popular in Indonesia owing to various obstacles in terms of social, cultural, and religious aspects. Rejection of recycled water due to disgust and contamination sensitivity, sometimes referred to as "the yuck factor", affects the use of recycled water significantly (Rozin et al., 2015). In countries such as Indonesia, religion is also an important factor in relation to recycled water acceptance. Although the Indonesian Council of Ulama (MUI) has affirmed the halal status of recycled water in Fatwa of MUI No. 2 of 2010 (Rachmadhi, 2016), most people still doubt the safety of recycled water.

Despite these obstacles, there are still many opportunities for water recycling implementation. It is often cheaper and more equitable to increase the efficiency of existing water sources than to increase supplies (Arrojo, 1999). In terms of water quality, there are opportunities to utilize the effluent of wastewater treatment because its quality is monitored and maintained through effluent standards. Therefore, a best practice study of water recycling and a water recycling opportunity analysis need to be conducted. This study reviews the strategy of water recycling implementation for the business sector in order to reduce groundwater and surface water consumption in Greater Jakarta. This study also aims to compile a best practice for water recycling by the early adopters from the business sector, since water recycling has already been implemented in some locations in Jakarta, but no documentation has been published.

\section{METHODOLOGY}

\subsection{Best Practice Study of Water Recycling}

A best practice study was conducted to identify the condition of water recycling implementation and to establish a strategy for the future. This study was carried out among various business sectors in Greater Jakarta that have already implemented water recycling. The research sample includes eight locations, as presented in Table 1.

Table 1 Study locations

\begin{tabular}{llcc}
\hline Manufacturing Industry & Commercial & Property & Office Building \\
\hline Bogasari & Senayan City & Regatta Apartment & Ministry of Public Works and Housing \\
Kimia Farma & Pacific Place & - & - \\
Frisian Flag Indonesia & Plaza Indonesia & - & - \\
\hline
\end{tabular}

\subsubsection{Data collection}

The primary data were obtained through semi-structured interviews and observations. The semi-structured interviews were based on the semi-structured interview guide, a schematic presentation of questions or topics that were explored by the interviewer (DiCicco-Bloom \& Crabtree, 2006). The interviewer had some discretion about the order of questions he/she would ask, but the questions themselves were standardized, and probes could be utilized to ensure that the researcher covered the intended material (Harrell \& Bradley, 2009). In this study, the issues discussed during the interview included: the background of the study location; motives for water recycling implementation; roles and relationships between the involved stakeholders; approvals and agreements; and risks, costs, benefits, and problems found during the implementation of water recycling. Moreover, physical observations of the water recycling plant were also conducted to validate some data obtained during the interview.

Secondary data were obtained through desk reviews based on documents and reports provided by the management of each study location. These reviewed documents and reports contained 
detailed descriptions of processing technologies, engineering drawings, stakeholders, monitoring systems, water quality, and water usage. Also included were the agreement and approval papers for water recycling projects, documents relating to water quality, environmental impact assessments, water balances, and environmental management for water recycling implementation.

\subsubsection{Data analysis}

Data analysis was carried out based on the guidance steps proposed by Harrell and Bradley (2009). Information was compiled by replaying and transcribing the interview recordings. After the transcription of the interviews, an analytical framework was created in order to identify the main ideas and key points based on the topics discussed.

\section{RESULTS AND DISCUSSION}

\subsection{Current Water Recycling Implementation in Business Sectors of Greater Jakarta}

Based on the study of the eight locations, saving money on water bills is the main purpose for the implementation of water recycling. This was mostly driven by the high price of water from water companies. However, the economic benefit is not the only motivation for water recycling implementation (see Figure 1). Other reasons identified are the commitment of the company itself and the urge to become a role model for other companies. A company's commitment to improve environmental performance is usually stated in their company policy or regulations. For instance, Frisian Flag Indonesia (FFI) has a policy called "Route 2020", with an aim to reduce their water use by $20 \%$ through the implementation of water reuse. The urge to become a role model was identified in the Ministry of Public Works and Housing, which has high influence as part of the central government.

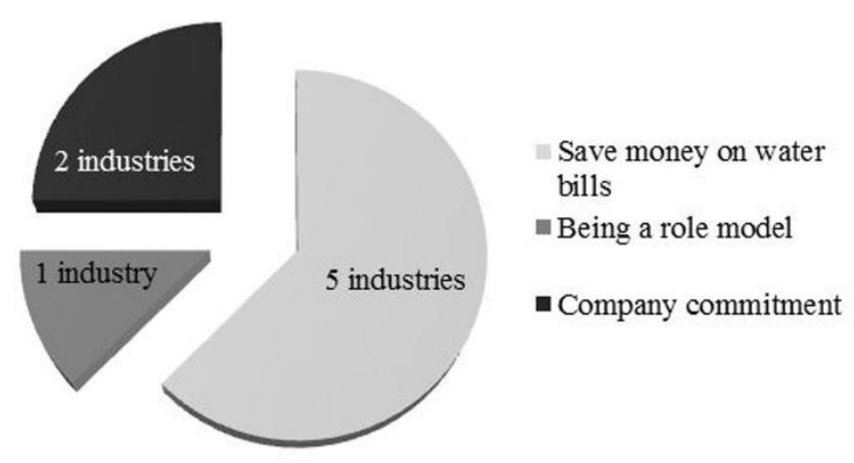

Figure 1 Main purpose for recycling water

Among the eight locations, only four were able to disclose the amount of their cost savings due to water recycling implementation. Bogasari and Kimia Farma could save IDR $12,550 / \mathrm{m}^{3}$, which is equal to IDR 5.6 million per month. Meanwhile, Plaza Indonesia, with a larger flowrate of recycled water consumption, could save up to IDR 83 million per month. However, this savings amount has not yet been deducted from the operating costs of the water recycling unit, which is categorized as the company's confidential data. FFI, which was willing to provide the operational cost data of its water recycling unit, admitted that it could gain water cost savings of up to IDR 1.2 million per month, based on a water price saving of IDR $280.23 / \mathrm{m}^{3}$ compared by Regional Water Supply Company (PDAM) water price (see Table 2). 
Table 2 Operational cost of water recycling unit at FFI (September 2016)

\begin{tabular}{lr}
\hline Filter Replacement Cost (IDR) & $19,980,000$ \\
\hline Chemical Cost (IDR) & $28,742,000$ \\
\hline Electricity Cost (IDR) & $5,664,600$ \\
\hline Maintenance Cost (IDR) & 164,384 \\
\hline \hline Monthly Total Operational Costs (IDR) & $54,550,984$ \\
\hline Monthly Total Recycled Water Produced ( ${ }^{3}$ ) & 4,446 \\
\hline Cost of Recycled Water per m ${ }^{3}$ (IDR) & $12,269.68$ \\
\hline Cost of Water Charged by PDAM per m ${ }^{3}$ (IDR) & 12,550 \\
\hline
\end{tabular}

Operational costs included filter replacement, chemical purchases, and electricity and maintenance expenses. The largest portion of the operational costs were chemical expenses. FFI used a physical-chemical treatment unit called Curieau ${ }^{\circledR}$. The flow diagram of Curieau ${ }^{\circledR}$ is shown in Figure 2. The process consists of two phases. In the first phase, solids in the water are removed by media filtration and then polymeric residues are oxidized in the oxidation chamber. After that, the water flows into an activated carbon treatment in order to remove free chlorine residues. Effluents from the first phase are collected in an intermediate buffer tank and the treatment continues to the second phase. In the second phase, the water is filtered through a membrane in reverse osmosis. Subsequently, a marble filter improves the hardness level of the water so that it becomes less corrosive. Finally, UV disinfection removes the remaining bacteria to produce an effluent that meets the standard of potable water.

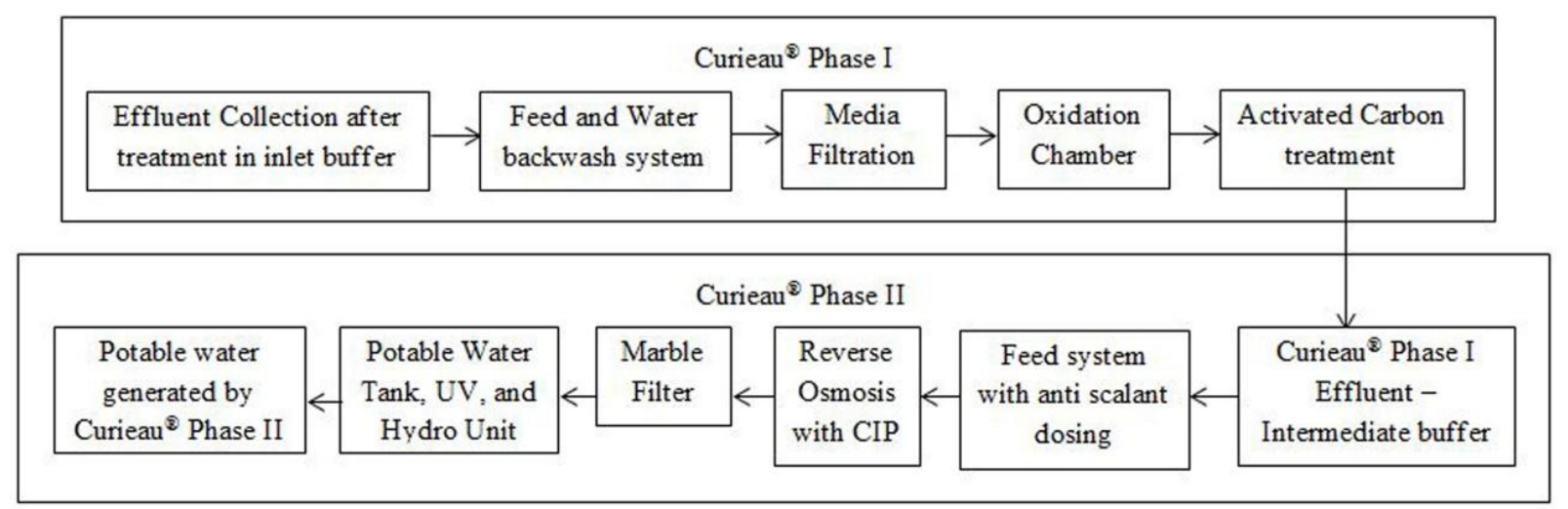

Figure 2 Simplified flow diagram of water recycling process at Frisian Flag Indonesia

FFI acknowledged that its cost saving amount has not been significant nominally. However, in terms of volume, the saving amount is quite significant, at around $4,446 \mathrm{~m}^{3} / \mathrm{month}$. This achievement constitutes a good step toward the company's water saving target of $20 \%$ by 2020 .

Recycled water can be used for a variety of purposes. Based on the study, most business sectors use recycled water on green area, which involves minimal direct contact with people, and for gardening and flushing (see Figure 3). This resulted from a business strategy to minimize negative responses that might arise due to social and religious barriers, such as "the yuck factor" and doubts about the water's halal status. Such negative responses from the public have been experienced by Senayan City, which first intended to educate society about water conservation by being featured in a news report using treated wastewater. However, the 
company received multiple negative reactions from people on social media who were disgusted by the use of recycled water.

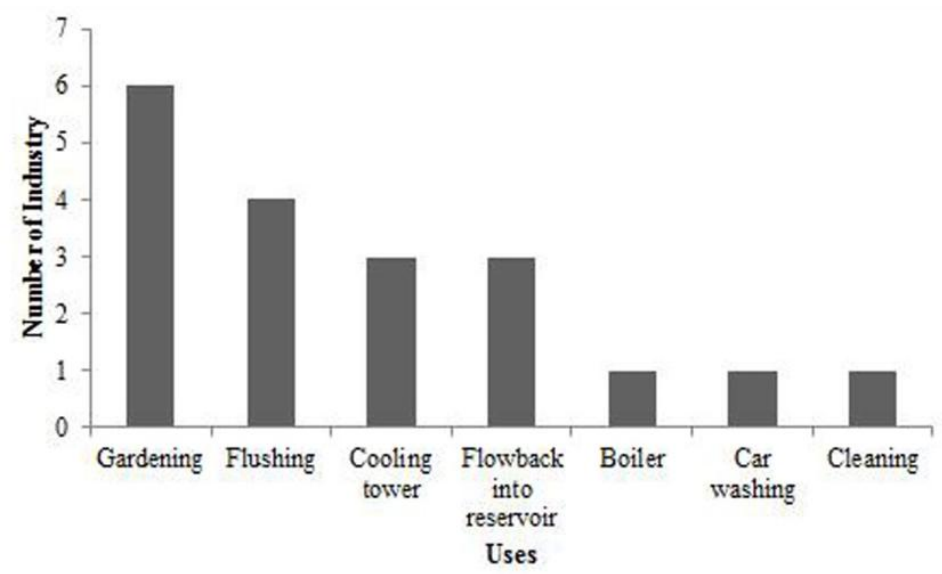

Figure 3 Recycled water uses

In general, the amount of recycled water used for gardening is considered insignificant when compared to the total water demand. However, in this study, it was found that several used water for gardening reaching up to $30 \%$ of the total water needed. Hence, the amount of recycled water used is quite substantial. Therefore, it has the potential to contribute significant economic advantages and to reduce water stress.

The use of recycled water, which was dominated by gardening, as seen in Figure 3, also indicated that the application of water recycling can be executed very easily and does not require extra plumbing or additional pipeline, both of which can be costly, especially for existing or old buildings. The "pick the low-hanging fruit" principle may be easily applied at the planning and implementing stages of water recycling. Supporting data showed that many business sectors implement water recycling with a medium flow rate of between 100 and 500 $\mathrm{m}^{3} /$ day (see Figure 4a).

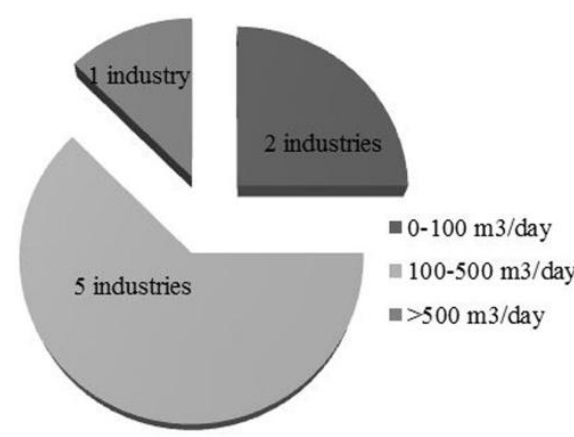

(a)

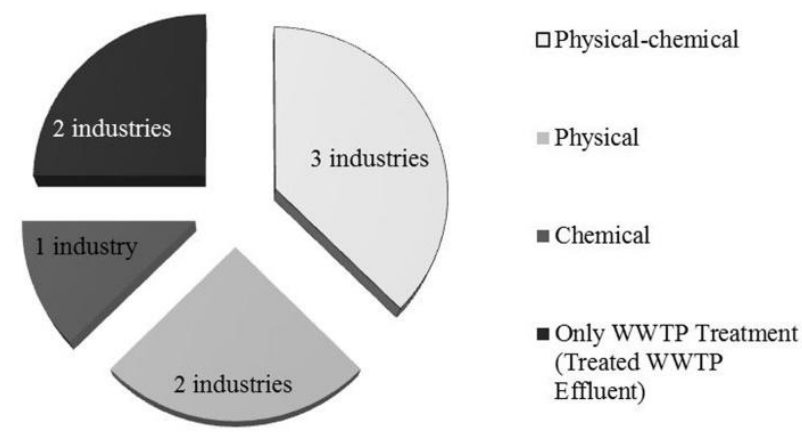

(b)

Figure 4 (a) Water recycling flowrate; (b) Water recycling technology

There are still many business sectors that use simple water treatment/recycling technology. Two of the study subjects even used the treated effluent of their wastewater treatment directly (see Figure $4 b$ ). This simple execution may encourage other business players who are eager to start implementing simple water recycling in their companies. 
Despite the challenges and risks of implementation, all study subjects admitted that water recycling yielded many benefits for them. The reuse of water helped their company to save money on water bills, upgraded their rating status appropriately, created environmental sustainability, and improved their company's image as being a role model either within their business sector or to other sectors. On the other hand, there were still risks that could arise, such as community rejection because of "the yuck factor" or doubts regarding halal status, some technical problems in unit treatment, and high investment costs. However, these challenges and risks could be reduced through mitigation from their internal stakeholders, and building support from the government and society. Better coordination between agencies and integrated government policies are required to achieve sustainable water recycling (Stenekes et al., 2006).

Mitigation from internal stakeholders of the studied companies included the policy of minimizing direct contact between recycled water and people, and hiring qualified vendors to focus on monitoring, and problem solving. Furthermore, a successful communication program is needed to build trust between organizations and stakeholders that can influence the level of community support for water recycling (Khan \& Gerrard, 2005). Strong leadership was also important since, in most cases, the initiative of water recycling came from top management, with strong commitment from specific individuals throughout the construction process until the operation phase. This finding is in line with those of a previous study by the Institute for Sustainable Futures (2013), which noted that strong personal commitment, deep experience, and the required knowledge and foresight to learn from past failures and ensure the success of the plant are major factors which contribute to effective water recycling.

\subsection{Policy Options for the Expansion of Water Recycling Implementation}

Despite various benefits, such as environmental sustainability and economic advantages, water recycling still comes with several problems that need to be mitigated. The interviewees from the best practice study recognized that, in order to expand water recycling implementation in Greater Jakarta as a sustainable solution to the water crisis problem, support from the government is urgently needed. The government can take a more active role in expanding water recycling implementation by facilitating the following steps:

1) Conduct the process of socialization and promotion of water recycling to the public and business sectors in cooperation with religious organizations, such as the Indonesian Council of Ulama (Majelis Ulama Indonesia), and encourage the involvement of social and environmental community organizations. These actions are intended to minimize the public's negative responses, improve society's awareness and knowledge of water recycling applications, and encourage various stakeholders to implement water recycling in their sectors. Water recycling projects in San Diego, California and in Singapore for instance have visitor centers that show the public an interactive, behind-the-scenes view of the technical operations involved in the water recycling process. These centers are integrated into their water recycling plants (Hummer \& Eden, 2016). Such an outreach program can steer public perception to support water recycling. The research findings of studies conducted in San Diego in 2004, 2011, and 2012 showed that the proportion of residents in favor of the use of advanced treated recycled water to diversify the city's water supply increased from 26\% in 2004 to $73 \%$ in 2012 (Steirer \& Thorsen, 2013). Beside the eight businesses interviewed for this study, many others have been contacted but came back with negative responses or were unwilling to participate. This demonstrates that the private sector has reservations about publicly exposing their water recycling process for fear of bad publicity, judgments or sanctions. This contrasts to the findings of Hartley (2006), who stated that promoting communication and public dialog is crucial to building and maintaining public confidence. 
2) Provide a legal framework, such as regulations, policies, and quality standards, which specifically regulates water recycling, as well as a transparent and accessible Standard Operational Procedure of proposing water recycling permits. Currently, the water quality standard used is Regulation Governor of Jakarta Number 122 Year 2005, although there is a specific water quality standard for clean water (as opposed to drinking water) which is regulated by Regulation of the Health Minister No. 416 Year 1990. There needs to be a more specific and explicit regulation for recycled water; examples of such regulation include: US EPA Guidelines for Water Reuse, Australian Guidelines for Water Recycling, and Spain Reclaimed Water Use Decree. Nevertheless, the Indonesian government needs to set realistic standards based on the best available technology, as well as the financial capacity of the business sector, while ensuring optimal health and environmental protection.

3) Provide technical assistance for risk assessment and risk minimization. Wider implementation of water recycling systems in the future will also improve public health and decrease social risk. The government will need to take a preventive approach to risk reduction in order to avoid future hazards and bad publicity for the concept of water recycling.

4) Introduce economic instruments, such as incentives for the business sectors that implement water recycling, and penalties for excessive use of groundwater and water from water companies. Singapore, for instance, provides NEWater, brand-named reclaimed water from Singapore's Public Utilities Board, at a lower rate than regular water and the government does not charge the Water Conservation Tax (30\% of the tariff charge for industrial users) on NEWater sales. This has helped Singapore to increase its water recycling application from $0 \%$ in 1998 to $30 \%$ in 2010 (GE Power \& Water, 2011). Another example is the United States: in April 2015, the Governor of California issued an Executive Order that directed the State Water Resources Control Board to devise a plan to reduce urban water use by $25 \%$ across the state. In response, the Metropolitan Water District of Southern California passed regulations that tripled the cost of water for those who exceeded the water use limit (Freedman et al., 2016).

5) Integrate water reuse strategies into national, regional, and local water management policies and targets. At present, water reuse is only a private and sectoral initiative, without any real outlook on its benefits and contribution on a wider scale.

In addition to contributions from the government, the private sector can also play a significant role in increasing water recycling implementation. First, it is preferable to plan ahead for a water recycling system during the construction phase to prevent space and safety constraints (Institute of Sustainable Futures, 2013). Second, it is recommended that a further feasibility study be performed in order to evaluate the option of installing a water recycling system on-site for each building or a communal off-site system.

\section{CONCLUSION}

A best practice study of water recycling in Greater Jakarta showed that the main driver for the business sector is saving costs on water bills. Recycled water is mostly used for purposes with minimal direct contact to minimize negative responses from the public. This practice will be best suited to industries with excellent Waste Water Treatment Plant (WWTP). Support from the government is essential for the expansion of water recycling implementation in Jakarta, particularly in terms of providing the publicity, regulation and technical assistance needed by the industry. 


\section{ACKNOWLEDGEMENT}

This study is funded by a grant of the Indonesian Directorate of Research and Higher Education under a grant of the National Priority Research for the Masterplan of Acceleration and Expansion of Indonesian Economic Development in 2016 of grant contract no. 1013/UN2.R12/HKP.05.00/2016. The authors would like to thank staff and interviewers who are not included as co-authors; all business sectors willing to become our research subjects; Sanitation \& Environment Laboratory Universitas Indonesia; and the laboratory assistants. We would also like to thank colleagues for their valuable input.

\section{REFERENCES}

Apip, Sagala S.A.H., Pingping L., 2015. Overview of Jakarta Water-related Environmental Challenges. Water and Urban Initiative, Working Paper Series, Volume 4, pp. 1-5

Arrojo, P., 1999. The Impact of Irrigation Water Pricing Policy in Spain. In: Proceedings of Pricing Water: Economics, Environment and Society, Sintra, Sept. 6-7, 1999, pp. 177-184

Corsita, L., Arwin, A., Muntalif, B.S., Salami, I.R., 2014. Assessment of the Water Quality of Jatiluhur Reservoir, the Downstream of Citarum Cascade River, using Selected Physicochemical Parameters. Jurnal Rekayasa Kimia \& Lingkungan, Volume 10(1), pp. 40-48

Delinom, R.M., 2008. Groundwater Management Issues in the Greater Jakarta Area, Indonesia. In: Proceedings of International Workshop on Integrated Watershed Management for Sustainable Water Use in Humid Tropical Region. Report JSPS-DGHE Joint Research Project, Tsukuba, Japan, Volume 8, pp. 40-54

DiCicco-Bloom, B., Crabtree, B.F., 2006. The Qualitative Research Interview. Medical Education, Volume 40(4), pp. 314-321

Freedman, J., Tseng, J., Meeker, M., Vallero, M., 2016. Addressing Water Scarcity through Recycling and Reuse: A Menu for Policymakers. Available online at https://www.tratamentodeagua.com.br/wp-content/uploads/2017/03/tratando-da-escassezde-agua-0317.pdf, Accessed on 22 June 2017

GE Power \& Water, 2011. Creating Effective Incentives for Water Reuse and Recycling. Available online at http://www.sustainableplant.com/assets/GE-White-Paper-CreatingEffective-Incentives-White-Paper.pdf, Accessed on 22 June 2017

Hamzah, H., 2016. Water Quality Status of Jatiluhur Reservoir and Threat to Vital Business Processes (Status Mutu Air Waduk Jatiluhur dan Ancaman Terhadap Proses Bisnis Vital). Jurnal Sumber Daya Air, Volume 13(1), pp. 47-60 (in Bahasa)

Harrell, M.C., Bradley, M.A., 2009. Data Collection Methods: Semi-Structured Interview and Focus Groups. RAND Corporation, California, USA

Hartley, T.W., 2006. Public Perception and Participation in Water Reuse. Desalination, Volume 18(1-3), pp. 115-126

Hidayatno, A., Moeis, A.O., Sutrisno, A., Maulidiah, W., 2015. Risk Impact Analysis on the Investment of Drinking Water Supply System Development using Project Risk Management. International Journal of Technology, Volume 6(5), pp. 894-904

Hummer, N., Eden, S., 2016. Potable Reuse of Water. Arroyo, University of Arizona Water Resources Research Center, Tucson, AZ. Available online at http://wrrc.arizona.edu/publications/arroyo-newsletter/arroyo-2016-Potable-Reuse-ofWater, Accessed on 22 June 2017

Institute for Sustainable Futures, 2013. Darling Quarter Case Study: Successful Sewage Recycling within a High Profile Commercial Building. Australia

Khan, S.J., Gerrard, L.E., 2005 Stakeholder Communications for Successful Water Reuse Operations. In: Proceedings of the International Conference: Integrated Concepts in Water 
Recycling 2005. Environmental Engineering, University of Wollongong, Australia, pp. 355-367

Ministry of Public Works, 2014. Infrastructure Investment Opportunity Field of Public Works, Center for Strategic Studies Ministry of Public Works (Peluang Investasi Infrastruktur Bidang Pekerjaan Umum, Pusat Kajian Strategis Kementerian Pekerjaan Umum). Report. (in Bahasa)

Rachmadhi, A.H., 2016. Greywater Recycling Potential for Operational Water Necessity: Study of Utilization Waste Ablution Water for Non-consumption Water Necessity in Istiqlal Mosque, DKI Jakarta (Potensi Daur Ulang Greywater untuk Kebutuhan Air Operasional, Kajian: Pemanfaatan Air Bekas Wudhu untuk Kebutuhan Air Non-Konsumsi di Masjid Istiqlal, DKI Jakarta). Post-graduate Thesis, Universitas Indonesia, Depok (in Bahasa)

Rozin, P., Haddad, B., Nemeroff, C., Slovic, P., 2015. Psychological Aspects of the Rejection of Recycled Water: Contamination, Purification and Disgust. Judgment and Decision Making, Volume 10(1), pp. 50-63

Steirer, M.A., Thorsen, D., 2013. Potable Reuse: Developing a New Source of Water for San Diego. Journal American Water Works Association, Volume 105(9), pp. 64-69

Stenekes, H., Colebatch, H.K., Waite, T.D., Ashbolt, N.J., 2006. Risk and Governance in Water Recycling: Public Acceptance Revisited. Science, Technology, \& Human Values, Volume 31(2), pp. 107-134

US EPA, 2012. Guidelines for Water Reuse. US Environmental Protection Agency, Washington DC, USA 